\title{
Improving Sugarcane Productivity through Single Eye Bud Settling by Adopting Different Inter and Intra Row Spacing of Sugarcane
}

\author{
D. S. Thorave ${ }^{*}$, J. D. Thanki and K. B. Patil \\ Department of Agronomy, N.M. College of Agriculture, Navsari, \\ Navsari Agricultural University, Navsari, Gujarat, India \\ *Corresponding author
}

Ke y w o r d s
$\begin{aligned} & \text { Sugarcane, } \\ & \text { Productivity } \\ & \text { and Settling }\end{aligned}$
Article Info
Accepted:
04 September 2020
Available Online:
10 October 2020

\section{A B S T R A C T}

\section{Introduction}

India is the second largest producer of sugarcane after Brazil cultivated sugarcane on 4.73 million hectares area with production of 376 million tonnes of sugarcane, 32.32 million tonnes of sugar and $10.73 \%$ sugar recovery with an average productivity 79.60 t/ha during 2017-18 (Anonymous, 2019). Gujarat state cultivating sugarcane crop on area of 1.82 lakh hectares with production of 120.52 lakh tonnes of sugarcane and 10.67 
lakh tonnes of sugar, $10.19 \%$ sugar recovery with an average productivity $66.22 \mathrm{t} /$ ha during 2017-18 (Anonymous, 2019).

Among different agronomic management practices, row spacing influences sugarcane productivity by maintaining adequate stalk population per unit area. Plant population in row crops is based on the spacing between two adjacent rows (inter row) and spacing between plants within row (intra row). Planting geometry plays an important role in water use efficiency, interception of solar radiation and evaporation. Row spacing is considered to be the most important planting geometry parameter in sugarcane. Row spacing determines tiller development and effective utilization of incident solar radiation and its conversion to biomass and stalk yield. Hence, it is imperative to identify such planting geometry, which maintains plant population, improves light interception, enhances nutrient availability, increases water use and facilitates intercropping and mechanization of sugarcane agriculture. Plant spacing is the critical one for providing proper nutrition, water and light to the crop plants. It is, therefore, essential that a suitable and effective area must be provided to a plant by growing it under suitable row to row and plant to plant distance or suitable planting technique (Babar et al., 2011). Therefore this research serves to come up standard intra row plant spacing that can be adopted by sugarcane grower so as to attain high returns.

South Gujarat is the main sugarcane belt in a state. Favourable climatic condition and sugar factories enhanced farmers for growing sugarcane crop. It has been reported that sugarcane yields of $341 \mathrm{t} / \mathrm{ha}$ were achieved by adopting wide row spacing in Vapi (South Gujarat) conditions (MangalRai, 2002). Sugarcane planting is done by conventional methods like 2 or 3 budded setts. South Gujarat has good potential of expanding area under sugarcane by adopting alternative planting method like sugarcane settling. Progressive farmers are adopting settling planting material for sugarcane planting. However, no adequate information is so far available on inter and intra row spacing of sugarcane by using single eye bud settling in Gujarat. Keeping aforesaid all points in view, the present research work was planned to find out suitable inter and intra row spacing of sugarcane by using single eye bud settling for incresing sugarcane productivity.

\section{Materials and Methods}

An experiment was conducted during 2017-18 and 2018-19 at Main Sugarcane Research Station, Navsari, Navsari Agricultural University, Gujarat, India. It comprised total sixteen treatments of four inter row spacing viz., planting of single eye bud settling at 105 $\mathrm{cm}$ row spacing $\left(\mathrm{R}_{1}\right)$, planting of single eye bud settling at $120 \mathrm{~cm}$ row spacing $\left(\mathrm{R}_{2}\right)$, planting of single eye bud settling at $135 \mathrm{~cm}$ row spacing $\left(\mathrm{R}_{3}\right)$ and planting of single eye bud settling at $150 \mathrm{~cm}$ row spacing $\left(R_{4}\right)$ and four intra row spacing viz., planting of single eye bud settling at $45 \mathrm{~cm}\left(\mathrm{~S}_{1}\right)$, planting of single eye bud settling at $60 \mathrm{~cm}$ intra row spacing $\left(S_{2}\right)$, planting of single eye bud settling at $75 \mathrm{~cm}$ intra row spacing $\left(\mathrm{S}_{3}\right)$ and planting of single eye bud settling at $90 \mathrm{~cm}$ intra row spacing $\left(\mathrm{S}_{4}\right)$ were evaluated in split plot design with three replications. Single eye bud settlings were transplanted as per different treatments of inter and intra row spacing. Single eye bud settlings of sugarcane variety CoN 05071 were planted in first week of December, 2017 and 2018 and harvested in the first week of December, 2018 and 2019. Recommended doses of fertilizers were applied to sugarcane $\left(\mathrm{N}: \mathrm{P}_{2} \mathrm{O}_{5}: \mathrm{K}_{2} \mathrm{O} 250: 115\right.$ : $115 \mathrm{~kg} / \mathrm{ha}) . \mathrm{N}$ was applied in four splits (15\% at planting, $30 \%$ at 6-8 weeks after planting, $20 \%$ at $12-16$ weeks after planting and $35 \%$ at earthing up) and dose of $\mathrm{P}$ and $\mathrm{K}$ fertilizers 
(50\% at the time of planting and $50 \%$ at the time of earthing up). Data obtained from the experiment was statistically analyzed by standard statistical methods from Panse and Sukhatme (1967) and Gomez and Gomez (1984).

\section{Results and Discussion}

\section{Effect on growth attributes}

\section{Effect of row spacing}

The number of tillers per hectare at 90, 120, 180 days after planting and number of shoots at 240 days after planting (Table 1) were significantly influenced by different inter row spacing. On the basis of pooled results, the number of tillers per hectare at 90, 120, 180 days after planting (48698, 59317, 51145 thousand/ha, respectively) and number of shoots per hectare at 240 days after planting (50667 thousand/ha) were significantly higher with planting of single eye bud settling at 120 $\mathrm{cm}\left(\mathrm{R}_{2}\right)$ and found at par with planting of single eye bud settling at $105 \mathrm{~cm}\left(\mathrm{R}_{1}\right)$.

The reason for higher number of tillers and number of shoots might be due to efficient light interception, nutrients, water, adequate space, aeration and lesser inter row plant competition at 120 inter row spacing. As inter row spacing increased, the number of settlings per hectare is reduced which results into lower number of tillers and number of shoots. These results are in agreement with Bhatnagar (2003), Yadav et al., (2014), Khalid et al., (2015), Chandrasekaran et al., (2017), Chaudhari et al., (2018), Galal (2018) and Chandrakar et al., (2019).

\section{Effect of intra row spacing}

The number of tillers at 90,120, 180 days after planting and number of shoots at 240 days after planting (Table 1) were significantly influenced by different intra row spacing. On the basis of pooled findings, significantly higher number of tillers per hectare at 90, 120, 180 days after planting (52271, 63667, 55005 thousand/ha, respectively) and number of shoots per hectare at 240 days after planting (54471 thousand/ha) under planting of single eye bud settling at $60 \mathrm{~cm}\left(S_{2}\right)$ and remained at par with planting of single eye bud settling at 45 $\mathrm{cm}\left(\mathrm{S}_{1}\right)$.

These results might be attributed to higher number of settlings and consequently higher tillers/ha. This might be due to adequate space within the plants compare to $75 \mathrm{~cm}$ and $90 \mathrm{~cm}$ intra row spacing facilitated the production of higher number of tillers. This is in agreement with the findings reported by Raskar (2002), Pawar et al., (2005), Chaudhari et al., (2018) and Galal (2018).

\section{Interaction effect}

The interaction effect between different inter and intra row spacing were significantly influenced on number of tillers at 90, 120 and 180 days after planting and number of shoots at 240 days after planting in pooled analysis. The treatment combination $120 \mathrm{~cm} \times 60 \mathrm{~cm}$ inter and intra row spacing, respectively $\left(\mathrm{R}_{2} \mathrm{~S}_{2}\right)$ recorded significantly higher number of tillers at 90, 120, 180 (59449, 72421, 62620 thousand/ha, respectively) and number of shoots at 240 days after planting (62078 thousand/ha) (Table 1a) and remained at par with $120 \mathrm{~cm} \times 45 \mathrm{~cm}\left(\mathrm{R}_{2} \mathrm{~S}_{1}\right)$ during both the years and in pooled analysis.

This might be due to adequate number of settlings which gets sufficient space, water and sunlight for photosynthesis resulted in production of more tillers and shoots. Similar results were reported by Chaudhari et al., (2018) and Galal (2018). 


\section{Effect on yield attributes and yield}

\section{Effect of inter row spacing}

Among different parameters related to yield viz., millable cane height, cane girth, number of internodes per cane, number of millable canes, average cane weight and cane yield (Table 2) were significantly influenced by various inter row spacing are described. On the basis of pooled data, millable cane height at harvest $(276.67 \mathrm{~cm})$ was significantly higher under planting of single eye bud settling at $150 \mathrm{~cm}$ row spacing $\left(\mathrm{R}_{4}\right)$ and found at par with planting of single eye bud settling at $135 \mathrm{~cm}$ row spacing $\left(\mathrm{R}_{3}\right)$. Significantly higher cane girth at harvest $(6.37 \mathrm{~cm})$ was produced under planting of single eye bud settling at $150 \mathrm{~cm}$ row spacing $\left(\mathrm{R}_{4}\right)$ being remained at par with planting of single eye bud settling at $R_{2}(120 \mathrm{~cm})$ and $R_{3}(135 \mathrm{~cm})$. The maximum number of internodes per cane at harvest (28.96) reported significantly under planting of single eye bud settling at $150 \mathrm{~cm}$ row spacing $\left(\mathrm{R}_{4}\right)$ over rest of inter row spacing. Higher average cane weight at harvest $(2.12 \mathrm{~kg})$ produced significantly under planting of single eye bud settling at $150 \mathrm{~cm}$ row spacing $\left(\mathrm{R}_{4}\right)$ being remained at par with planting of single eye bud settling at $120 \mathrm{~cm}$ row spacing $\left(\mathrm{R}_{2}\right)$. Higher yield attributes like millable cane height, cane girth, number of internodes per cane and average cane weight under wider row spacing might be due to the availability of optimum of nutrient, water and light utilization that does not create any sort of competition whereas in case of closer spacing might built some sort of competition. Similar results are reported by Bhatnagar (2003), Mokashi (2005) and Ullah et al., (2016). Significantly higher number of millable canes at harvest (50113 thousand/ha) was recorded under the treatment of planting of single eye bud settling at $120 \mathrm{~cm}\left(\mathrm{R}_{2}\right)$ and remained at par with planting of single eye bud settling at $105 \mathrm{~cm}\left(\mathrm{R}_{1}\right)$. This was largely attributed to more efficient utilization of moisture, nutrients and solar energy which gave higher numbers of millable canes per hectare than closed row spacing. Above results are in line with findings of Devi et al., (2014), Singh and Brar (2015), Singh et al., (2016) and Chaudhari et al., (2018).

Planting of single eye bud settling at $120 \mathrm{~cm}$ $\left(\mathrm{R}_{2}\right)$ resulted in significantly higher cane yield (94.48 t/ha) and remained at par with planting of single eye bud settling at $135 \mathrm{~cm}\left(\mathrm{R}_{3}\right)$. This might be due to optimum plant population and availability of ample sunlight which results into higher number of millable canes per hectare with maximum millable cane height, cane girth, number of internodes and average cane weight. The present findings are in close agreement with the results obtained by Chattha et al. (2007), Khandagave (2011), Gouri et al., (2014), Khalid et al., (2015), Singh et al., (2016). Chaudhari et al., (2018) and Chandrakar et al., (2019).

\section{Effect of intra row spacing}

Among different parameters related to yield viz., millable cane height, cane girth, number of internodes per cane, number of millable canes, average cane weight and cane yield were significantly influenced by various intra row spacing.

Millable cane height $(276.54 \mathrm{~cm})$ and number of internodes per cane (26.96) at harvest resulted in significantly higher under planting of single eye bud settling at $90 \mathrm{~cm}\left(\mathrm{~S}_{4}\right)$ which was at par with planting of single eye bud settling at $75 \mathrm{~cm}\left(\mathrm{~S}_{3}\right)$. The cane girth at harvest $(6.40 \mathrm{~cm})$ reported significantly higher under planting of single eye bud settling at $90 \mathrm{~cm}\left(\mathrm{~S}_{4}\right)$ being remained at par with planting of single eye bud settling at 75 $\mathrm{cm}\left(\mathrm{S}_{3}\right)$. Planting of single eye bud settling at $90 \mathrm{~cm}\left(\mathrm{~S}_{4}\right)$ registered significantly superior average cane weight $(2.25 \mathrm{~kg})$ over other intra 
row spacing. Increase in intra row spacing from 45 to $90 \mathrm{~cm}$ improved millable cane height, cane girth, number of internodes per cane and average cane weight. This might be due to severe competition for space, sun light and other growth factors for closer spacing as compared to wider intra row spacing which enjoyed the benefit of proper space and light for development of plants. These results are in corroborate with Bhatnagar (2003), Raskar and Bhoi (2003), Pawar et al., (2005) and Chaudhari et al., (2018).

Number of millable canes per hectare at harvest (53897 thousand/ha) reported significantly higher under planting of single eye bud settling at $60 \mathrm{~cm}\left(\mathrm{~S}_{2}\right)$ which remained at par with planting of single eye bud settling at $45 \mathrm{~cm}\left(\mathrm{~S}_{1}\right)$.

Table.1 Number of tillers and number of shoots of sugarcane (thousand/ha) as influenced by different inter and intra row spacing (Pooled data)

\section{Treatment}

(A) Main plot factors (Inter row spacing)

$R_{1}$ : Planting of single eye bud settling at $105 \mathrm{~cm}$

$R_{2}$ : Planting of single eye bud settling at $120 \mathrm{~cm}$

$R_{3}$ : Planting of single eye bud settling at $135 \mathrm{~cm}$

$R_{4}$ : Planting of single eye bud settling at $150 \mathrm{~cm}$

SEm \pm

$\mathrm{CD}(\mathbf{P}=\mathbf{0 . 0 5})$

CV (\%)

(B) Sub plot factors (Intra row spacing)

$S_{1}$ : Planting of single eye bud settling at $45 \mathrm{~cm}$

$S_{2}$ : Planting of single eye bud settling at $60 \mathrm{~cm}$

$\mathrm{S}_{3}$ : Planting of single eye bud settling at $75 \mathrm{~cm}$

$S_{4}$ : Planting of single eye bud settling at $90 \mathrm{~cm}$

SEm \pm

$\mathrm{CD}(\mathrm{P}=0.05)$

CV (\%)

\section{Interaction (M x S)}

SEm \pm

$\mathrm{CD}(\mathrm{P}=\mathbf{0 . 0 5})$

CV (\%)

General mean

\section{Number of tillers of sugarcane \\ (thousand/ha)

\begin{tabular}{c|c|c|}
$\begin{array}{c}\text { 90 days } \\
\text { after } \\
\text { planting }\end{array}$ & $\begin{array}{c}120 \text { days } \\
\text { after } \\
\text { planting }\end{array}$ & $\begin{array}{c}180 \text { days } \\
\text { after } \\
\text { planting }\end{array}$ \\
\hline
\end{tabular}

\section{Number of shoots \\ (thousand/ha) \\ 240 days after planting}

\begin{tabular}{|c|c|c|c|}
\hline 47470 & 57632 & 49857 & 49269 \\
\hline 48698 & 59317 & 51145 & 50667 \\
\hline 41585 & 50736 & 43750 & 43306 \\
\hline 37519 & 45794 & 39447 & 39061 \\
\hline 951.82 & 1304.03 & 1153.05 & 1055.71 \\
\hline 2932.84 & 4018.13 & 3552.89 & 3252.96 \\
\hline 10.64 & 11.97 & 12.27 & 11.35 \\
\hline
\end{tabular}


Table.1a Interaction effect as influenced by different inter and intra row spacing on growth attributes of sugarcane

\begin{tabular}{|c|c|c|c|c|c|c|c|c|}
\hline \multirow{3}{*}{$\begin{array}{c}\text { Intra row } \\
\text { spacing } \\
\text { (S) }\end{array}$} & \multicolumn{4}{|c|}{ Number of tillers at 90 days after planting } & \multicolumn{4}{|c|}{ Number of tillers at 120 days after planting } \\
\hline & \multicolumn{8}{|c|}{ Inter row spacing $(\mathbf{R})$} \\
\hline & $\mathbf{R}_{1}$ & $\mathbf{R}_{2}$ & $\mathbf{R}_{3}$ & $\mathbf{R}_{4}$ & $\mathbf{R}_{1}$ & $\mathbf{R}_{\mathbf{2}}$ & $\mathbf{R}_{3}$ & $\mathbf{R}_{4}$ \\
\hline $\mathbf{S}_{1}$ & 51746 & 58611 & 50343 & 48296 & 62735 & 71435 & 61270 & 59068 \\
\hline $\mathbf{S}_{2}$ & 54579 & 59449 & 50741 & 44315 & 66344 & 72421 & 61872 & 54030 \\
\hline $\mathbf{S}_{3}$ & 47048 & 44648 & 38304 & 33911 & 57349 & 54411 & 46738 & 41367 \\
\hline $\mathbf{S}_{4}$ & 36506 & 32083 & 26953 & 23556 & 44101 & 39001 & 33063 & 28708 \\
\hline SEm \pm & \multicolumn{4}{|c|}{1200.12} & \multicolumn{4}{|c|}{1434.07} \\
\hline $\mathrm{CD}(\mathrm{P}=\mathbf{0 . 0 5})$ & \multicolumn{4}{|c|}{3413} & \multicolumn{4}{|c|}{4078} \\
\hline $\mathrm{CV}(\%)$ & \multicolumn{4}{|c|}{6.71} & \multicolumn{4}{|c|}{6.58} \\
\hline $\begin{array}{c}\text { Intra row } \\
\text { spacing }(S)\end{array}$ & \multicolumn{4}{|c|}{ Number of tillers at 180 days after planting } & \multicolumn{4}{|c|}{ Number of shoots at 240 days after planting } \\
\hline $\mathbf{S}_{1}$ & 54454 & 61591 & 52864 & 50769 & 53870 & 61047 & 52326 & 50287 \\
\hline $\mathbf{S}_{2}$ & 57472 & 62620 & 53363 & 46567 & 56854 & 62078 & 52838 & 46117 \\
\hline $\mathbf{S}_{3}$ & 49458 & 46904 & 40263 & 35668 & 48644 & 46430 & 39862 & 35301 \\
\hline $\mathbf{S}_{4}$ & 38045 & 33465 & 28509 & 24783 & 37709 & 33113 & 28199 & 24540 \\
\hline SEm \pm & \multicolumn{4}{|c|}{1205.47} & \multicolumn{4}{|c|}{1215.39} \\
\hline $\mathrm{CD}(\mathrm{P}=0.05)$ & \multicolumn{4}{|c|}{3428} & \multicolumn{4}{|c|}{3456} \\
\hline $\mathrm{CV}(\%)$ & \multicolumn{4}{|c|}{6.41} & \multicolumn{4}{|c|}{6.53} \\
\hline
\end{tabular}


Table.2 Effect of different inter and intra row spacing on yield attributes and yield of sugarcane at harvest

\begin{tabular}{|c|c|c|c|c|c|c|}
\hline Treatment & $\begin{array}{c}\text { Millable } \\
\text { cane height } \\
(\mathrm{cm})\end{array}$ & $\begin{array}{l}\text { Cane girth } \\
(\mathrm{cm})\end{array}$ & $\begin{array}{c}\text { Number of } \\
\text { internodes/cane }\end{array}$ & $\begin{array}{l}\text { Number of } \\
\text { millable cane } \\
\text { (thousand/ha) }\end{array}$ & $\begin{array}{c}\text { Average } \\
\text { cane } \\
\text { weight (kg) }\end{array}$ & $\begin{array}{l}\text { Cane yield } \\
\text { (t/ha) }\end{array}$ \\
\hline \multicolumn{7}{|l|}{ (A) Main plot factors (Inter row spacing) } \\
\hline $\begin{array}{l}R_{1} \text { : Planting of single eye bud settling at } 105 \\
\text { cm }\end{array}$ & 255.04 & 6.13 & 20.17 & 48869 & 1.68 & 75.98 \\
\hline $\begin{array}{l}R_{2} \text { : Planting of single eye bud settling at } 120 \\
\mathrm{~cm}\end{array}$ & 265.42 & 6.28 & 23.75 & 50113 & 2.03 & 94.48 \\
\hline $\begin{array}{l}R_{3}: \text { Planting of single eye bud settling at } 135 \\
\text { cm }\end{array}$ & 272.75 & 6.30 & 26.25 & 42888 & 2.10 & 86.85 \\
\hline $\begin{array}{l}R_{4} \text { : Planting of single eye bud settling at } 150 \\
\text { cm }\end{array}$ & 276.67 & 6.37 & 28.96 & 38670 & 2.12 & 78.22 \\
\hline SEm \pm & 1.54 & 0.03 & 0.52 & 1092.81 & 0.04 & 2.67 \\
\hline CD $(P=0.05)$ & 4.73 & 0.09 & 1.59 & 3367 & 0.13 & 8.24 \\
\hline CV $(\%)$ & 2.81 & 2.35 & 10.19 & 11.86 & 10.48 & 15.61 \\
\hline \multicolumn{7}{|l|}{ (B) Sub plot factors (Intra row spacing) } \\
\hline$S_{1}$ : Planting of single eye bud settling at $45 \mathrm{~cm}$ & 254.50 & 6.11 & 21.75 & 53832 & 1.53 & 79.30 \\
\hline$S_{2}$ : Planting of single eye bud settling at $60 \mathrm{~cm}$ & 266.25 & 6.25 & 24.42 & 53897 & 2.06 & 105.10 \\
\hline$S_{3}$ : Planting of single eye bud settling at $75 \mathrm{~cm}$ & 272.58 & 6.32 & 26.00 & 42225 & 2.08 & 85.05 \\
\hline$S_{4}$ : Planting of single eye bud settling at $90 \mathrm{~cm}$ & 276.54 & 6.40 & 26.96 & 30586 & 2.25 & 66.09 \\
\hline SEm \pm & 1.73 & 0.03 & 0.55 & 552.67 & 0.03 & 2.00 \\
\hline $\mathrm{CD}(\mathrm{P}=\mathbf{0 . 0 5})$ & 4.91 & 0.08 & 1.56 & 1572 & 0.09 & 5.69 \\
\hline CV $(\%)$ & 3.16 & 2.13 & 10.88 & 6.00 & 7.59 & 11.70 \\
\hline \multicolumn{7}{|l|}{ Interaction (M x S) } \\
\hline SEm \pm & 3.45 & 0.05 & 1.10 & 1105.34 & 0.06 & 4.01 \\
\hline $\mathrm{CD}(\mathrm{P}=0.05)$ & 9.82 & 0.16 & NS & 3143 & 0.17 & 11.39 \\
\hline $\mathrm{CV}(\%)$ & 3.16 & 2.13 & 10.88 & 6.00 & 7.59 & 11.70 \\
\hline General mean & 267.47 & 6.27 & 24.78 & 45135 & 1.98 & 83.88 \\
\hline
\end{tabular}


Table.2a Interaction effect as influenced by different inter and intra row spacing on yield attributes of sugarcane

\begin{tabular}{|c|c|c|c|c|c|c|c|c|c|c|c|c|}
\hline \multirow{3}{*}{$\begin{array}{c}\text { Intra row } \\
\text { spacing } \\
\text { (S) }\end{array}$} & \multicolumn{4}{|c|}{ Millable cane height $(\mathrm{cm})$ at harvest } & \multicolumn{4}{|c|}{ Cane girth $(\mathrm{cm})$ at harvest } & \multicolumn{4}{|c|}{$\begin{array}{c}\text { Number of millable cane } \\
\text { (thousand/ha) }\end{array}$} \\
\hline & \multicolumn{12}{|c|}{ Inter row spacing $(\mathbf{R})$} \\
\hline & $\mathbf{R}_{1}$ & $\mathbf{R}_{2}$ & $\mathbf{R}_{\mathbf{3}}$ & $\mathbf{R}_{\mathbf{4}}$ & $\mathbf{R}_{1}$ & $\mathbf{R}_{2}$ & $\mathbf{R}_{\mathbf{3}}$ & $\mathbf{R}_{\mathbf{4}}$ & 53359 & 60378 & 51822 & 49769 \\
\hline $\mathbf{S}_{1}$ & 225.33 & 258.83 & 264.00 & 269.83 & 5.72 & 6.22 & 6.25 & 6.28 & 56339 & 61288 & 52311 & 45650 \\
\hline $\mathbf{S}_{\mathbf{2}}$ & 260.50 & 262.67 & 268.00 & 273.83 & 6.21 & 6.26 & 6.23 & 6.30 & 48484 & 45980 & 39470 & 34965 \\
\hline $\mathbf{S}_{\mathbf{3}}$ & 266.17 & 267.17 & 277.17 & 279.83 & 6.27 & 6.29 & 6.34 & 6.37 & 37295 & 32806 & 27948 & 24295 \\
\hline $\mathbf{S}_{4}$ & 268.17 & 273.00 & 281.83 & 283.17 & 6.32 & 6.35 & 6.38 & 6.53 & 53359 & 60378 & 51822 & 49769 \\
\hline SEm \pm & \multicolumn{4}{|c|}{3.45} & \multicolumn{4}{|c|}{0.05} & \multicolumn{4}{|c|}{1105.34} \\
\hline $\begin{array}{l}\text { CD } \\
(P=0.05)\end{array}$ & \multicolumn{4}{|c|}{9.82} & \multicolumn{4}{|c|}{0.16} & \multicolumn{4}{|c|}{3143} \\
\hline CV (\%) & \multicolumn{4}{|c|}{3.16} & \multicolumn{4}{|c|}{2.13} & \multicolumn{4}{|c|}{6.00} \\
\hline \multirow{2}{*}{$\begin{array}{l}\text { Intra row } \\
\text { spacing }(S)\end{array}$} & \multicolumn{4}{|c|}{ Average cane weight $(\mathrm{kg})$} & \multicolumn{4}{|c|}{ Cane yield (t/ha) at harvest } & & & & \\
\hline & $\mathbf{R}_{1}$ & $\mathbf{R}_{2}$ & $\mathbf{R}_{3}$ & $\mathbf{R}_{\mathbf{4}}$ & $\mathbf{R}_{1}$ & $\mathbf{R}_{2}$ & $\mathbf{R}_{\mathbf{3}}$ & $\mathbf{R}_{\mathbf{4}}$ & & & & \\
\hline $\mathbf{S}_{1}$ & 1.44 & 1.48 & 1.58 & 1.64 & 71.46 & 86.02 & 80.26 & 79.44 & & & & \\
\hline $\mathbf{S}_{2}$ & 1.55 & 2.18 & 2.25 & 2.26 & 80.94 & 120.66 & 117.12 & 101.68 & & & & \\
\hline $\mathbf{S}_{\mathbf{3}}$ & 1.58 & 2.22 & 2.26 & 2.28 & 73.87 & 99.98 & 88.32 & 78.01 & & & & \\
\hline $\mathbf{S}_{4}$ & 2.16 & 2.26 & 2.29 & 2.30 & 77.64 & 71.27 & 61.70 & 53.77 & & & & \\
\hline SEm \pm & \multicolumn{4}{|c|}{0.06} & \multicolumn{4}{|c|}{4.01} & & & & \\
\hline $\begin{array}{l}\text { CD } \\
(P=0.05)\end{array}$ & \multicolumn{4}{|c|}{0.17} & \multicolumn{4}{|c|}{11.39} & & & & \\
\hline CV $(\%)$ & \multicolumn{4}{|c|}{7.59} & \multicolumn{4}{|c|}{11.70} & & & & \\
\hline
\end{tabular}


The cane yield at harvest (105.10 t/ha) recorded significantly superior with planting of single eye bud settling at $60 \mathrm{~cm}\left(\mathrm{~S}_{2}\right)$ over rest of intra row spacing. The increased number of millable canes and cane yield might be due to better light interception, greater availability of moisture, more aeration and efficient utilization of nutrients to optimum plant population. These results are in line with Pawar et al., (2005), Tayade et al., (2017) and Kumar (2019).

\section{Interaction effect}

The interaction effect between various inter and intra row spacing on millable cane height, cane girth, number of millable canes, average cane weight and cane yield at harvest (Table 2a) were significantly influenced in pooled results. However the interaction effect on number of internodes per cane failed to express its significant effect in pooled results. On pooled analysis data, treatment combination $150 \mathrm{~cm}$ x $90 \mathrm{~cm}\left(\mathrm{R}_{4} \mathrm{~S}_{4}\right)$ recorded significantly higher millable cane height at harvest $(283.17 \mathrm{~cm})$ and remained at par with $135 \mathrm{~cm} \mathrm{x} 75 \mathrm{~cm}\left(\mathrm{R}_{3} \mathrm{~S}_{3}\right), 135 \mathrm{~cm} \mathrm{x} 90 \mathrm{~cm}$ $\left(\mathrm{R}_{3} \mathrm{~S}_{4}\right), 150 \mathrm{~cm} \mathrm{x} 60 \mathrm{~cm}\left(\mathrm{R}_{4} \mathrm{~S}_{2}\right)$ and $150 \mathrm{~cm} \mathrm{x}$ $75 \mathrm{~cm}\left(\mathrm{R}_{4} \mathrm{~S}_{3}\right)$. Treatment combination $150 \mathrm{~cm}$ x $90 \mathrm{~cm}\left(\mathrm{R}_{4} \mathrm{~S}_{4}\right)$ recorded significantly higher cane girth at harvest $(6.53 \mathrm{~cm})$ and remained at par with $135 \mathrm{~cm} \times 90 \mathrm{~cm}\left(\mathrm{R}_{3} \mathrm{~S}_{4}\right)$ and 150 $\mathrm{cm} \times 75 \mathrm{~cm}\left(\mathrm{R}_{4} \mathrm{~S}_{3}\right)$. The average cane weight at harvest $(2.30 \mathrm{~kg})$ reported significantly higher under treatment combination $150 \mathrm{~cm} \mathrm{x}$ $90 \mathrm{~cm}\left(\mathrm{R}_{4} \mathrm{~S}_{4}\right)$ and remained at par with $\mathrm{R}_{1} \mathrm{~S}_{4}$, $\mathrm{R}_{2} \mathrm{~S}_{2}, \mathrm{R}_{2} \mathrm{~S}_{3}, \mathrm{R}_{2} \mathrm{~S}_{4}, \mathrm{R}_{3} \mathrm{~S}_{2}, \mathrm{R}_{3} \mathrm{~S}_{3}, \mathrm{R}_{3} \mathrm{~S}_{4}, \mathrm{R}_{4} \mathrm{~S}_{2}$ and $\mathrm{R}_{4} \mathrm{~S}_{3}$. This might be due to wider row and intra row spacing resulted in higher millable cane height, average cane weight and cane girth because less competition for resources likes nutrient, water and sunlight.

Treatment combination $120 \mathrm{~cm} \mathrm{x} 60 \mathrm{~cm}$ $\left(\mathrm{R}_{2} \mathrm{~S}_{2}\right)$ recorded significantly higher number of millable canes at harvest $(61288$ thousand/ha) which remained at par with 120 $\mathrm{cm} \times 45 \mathrm{~cm}\left(\mathrm{R}_{2} \mathrm{~S}_{1}\right)$. This might be due to proper utilization of resources like light, nutrients, water. Similar results are corroborate with Chaudhari et al., (2018), Galal (2018), Chandrakar et al., (2019) and Chaudhari (2019).

Treatment combination $120 \mathrm{~cm} \mathrm{x} 60 \mathrm{~cm}$ $\left(\mathrm{R}_{2} \mathrm{~S}_{2}\right)$ produced significantly higher cane yield at harvest (120.66 t/ha) which was at par with $135 \mathrm{~cm} \mathrm{x} 60 \mathrm{~cm}\left(\mathrm{R}_{3} \mathrm{~S}_{2}\right)$. The marked increase in yield appears due to better light interception, greater availability of moisture, more aeration to growth contributing characters like number of tillers and shoots as well as yield attributes like millable cane height, cane girth, number of internodes per cane, average cane weight, number of millable cane and average cane weight as compared to rest of the treatment combinations. These results are in agreement with Chaudhari et al., (2018), Galal (2018), Chandrakar et al., (2019) and Chaudhari (2019).

It is concluded from the study that for getting higher yield of sugarcane crop can be achieved with planting of single eye bud settlings at $120 \mathrm{~cm} \times 60 \mathrm{~cm}\left(\mathrm{R}_{2} \mathrm{~S}_{2}\right)$ inter and intra row spacing, respectively under south Gujarat condition.

\section{References}

Anonymous, 2019. Cooperative Sugar, 51(1): 46-61.

Babar, L. K., Iftikhar, T., Khan, H. N. and Makhdum, A. H. 2011. Agronomic trials on sugarcane crop under Faisalabad conditions, Pakistan. Pakistan Journal Botany, 43: 929-935.

Bhatnagar, A. 2003. Studies on planting geometry and fertilizer requirement of sugarcane under polybag system of transplanting in summer season. Ph.D. 
thesis submitted to G.B. Pant University of Agriculture and Technology, Pantnagar, Uttaranchal. Chandrakar, C. K., Prabha, N., Verma, O. N. and Pandey, K. K. 2019. Standardization of planting geometry of sugarcane with suitable intercropping under drip irrigation in Chhattisgarh plains. International Journal of Current Microbiology and Applied Science, 8(7): 2878-2884.

Chandrasekaran, R., Nageswari, R. and Ravi, V. 2017. Effect of plant geometry and intercropping under sustainable sugarcane initiative (SSI) in sugarcane. Proceedings of International Symposium on Sugarcane Research Since Co 205: 100 Years and Beyond (Sucrosym2017), pp. 508-510.

Chattha, M. U., Ali, A. and Bilal, M. 2007. Influence of planting techniques on growth and yield of spring planted sugarcane (Saccharum officinarum L.). Pakistan Journal of Agricultural Sciences, 44: 452-456.

Chaudhari, P. M., Ombase, K. C., Bhoite, D. S., Deshmukh, S. U., Solanke, A. V. and Pawar, S. M. 2018. Effect of row spacing and intra row spacing on growth and yield of preseasonal sugarcane. Proceedings of $64^{\text {th }}$ Annual Convention of The Deccan Sugar Technologists Association, pp. 66-77.

Chaudhari, N.N. 2019. Effect of planting material, spacing and nitrogen management on sugarcane seed crop production under south Gujarat condition. Ph.D. thesis submitted to Navsari Agricultural University, Navsari, Gujarat.

Devi, C. T., Kumari, M. B. G. S., Gouri V., Naidu, N.V. and Bharata Laxmi M. 2014. Agronomic management of cane crop raised with budchip seedlings. Proceedings of $44^{\text {th }}$ Annual
Convention of The South Indian Sugarcane and Sugar Technologists Association of India: 191-195.

Galal, M. O. A. 2018. Cane and sugar yields of promising sugarcane varieties as affected by row width and within-row spacing among seedlings. Indian Journal of Sugarcane Technology, 33(1): 8-14.

Gomez, K. A. and Gomez, A. A. (1984). Statistical procedure for Agricultural Research (II ${ }^{\text {nd }}$ edn). An International Rice Research Institute Book, John Willey and Sons, Inc., New York.

Gouri V., Devi, C. T., Bharata Laxmi M., Kumari, M. B. G. S. and Rao, K. P. 2014. Response of budchip and single bud seedlings of sugarcane to different planting methods and nitrogen levels under drip fertigation. Proceedings of $44^{\text {th }}$ Annual Convention of The South Indian Sugarcane and Sugar Technologists Association of India, pp. 125-129.

Khalid, S., Munsif, F., Ali, A., Ismail, M., Haq, N. and Shahid, M. 2015. Evaluation of chip bud settling of sugarcane for enhancing yield to various row spacing. International Journal of Agricultural and Environmental Research, 1(2): 8-13.

Khandagave, R. B. 2011. Wide row spacing in sugarcane a remedy for mechanized harvesting. Proceedings of $41^{\text {st }}$ Annual Convention of The South Indian Sugarcane and Sugar Technologists Association of India: 125-129.

Kumar, N. 2019. Enhancing sugarcane plantratoon productivity through bud chip transplanting geometry. Sugar Tech, https://doi.org/10.1007 /s12355-01900772-3.

MangalRai (2002). Varietal improvement in sugarcane: System perspective. Proc. International symposium on food, nutrition and economic security 
through diversification in sugarcane production and processing system, held at Lucknow, India, 13-38.

Mokashi, D. D. 2005. The study the effect of planting techniques and micro irrigation system on micro climatic changes and its relation on growth, development, yield and quality of suru sugarcane (Co 86032). Ph.D. thesis submitted to Mahatma Phule Krishi Vidyapeeth, Rahuri, Maharashtra.

Panse, V. G. and Sukhatme, P.V. 1967. Statistical methods for agricultural worker. Indian Council of Agricultural Research, New Delhi, India, pp.152161.

Pawar, M. W., More, D. B., Amodkar, V. T. and Joshi, S. 2005. Effect of intersettling spacing on sugarcane yield and quality. Sugar Tech, 7(1): 87-89.

Raskar, B. S. 2002. Response of sugarcane Co 86032 to planting materials, intra-row spacings and fertilizer levels under drip irrigation. Ph.D. thesis submitted to Mahatma Phule Krishi Vidyapeeth, Rahuri, Maharashtra.

Raskar, B. S. and Bhoi, P. G. 2003. Effect of intra-row spacings, fertilizer levels and planting materials on yield and economics of preseasonal sugarcane under drip irrigation. Sugar Tech, 5(4): 305-309.

Singh, K. and Brar, A.S. 2015. Effect of planting methods and irrigation schedules on cane yield, quality, economics and water productivity of spring sugarcane (Saccharum officinarum) in south western Punjab. Indian Journal of Agronomy, 60(4): 601-605.

Singh, S. C., Yadav, S., Yadav, S., Yadav, S. K., Tiwari, A. K. and Sharma, B. L. 2016. Studies on plant geometry and nutrient management strategy in relation to mechanization in sugarcane (Saccharum species hybrid). Agrica, 5: 116-118

Tayade, A. S., Geetha, P., Anusha, S. and Ram, B. 2017. Standardizing agrotechniques for true seed seedlings with special reference to intra-row spacings and planting depths. Proceedings of International Symposium on Sugarcane Research Since Co 205: 100 Years and Beyond (Sucrosym2017). pp. 542-543.

Ullah, S., Anjum, S. A., Raza, M. M., Riaz, A., Abbas, A., Yousif, M. M., Ma, J., Li, Y., Zhang, J., Cheng, D., Xu, Y. and Ali, I. 2016. Optimizing row spacing to ameliorate the productivity of spring sugarcane (Saccharum officinarum L.). Agricultural Sciences, 7: 531-538.

Yadav, R. L. 1984. Effect of methods of planting on yield and nutrient uptake by sugarcane. Indian Journal of Agronomy, 29(3): 322-326.

\section{How to cite this article:}

Thorave, D. S., J. D. Thanki and Patil, K. B. 2020. Improving Sugarcane Productivity through Single Eye Bud Settling by Adopting Different Inter and Intra Row Spacing of Sugarcane. Int.J.Curr.Microbiol.App.Sci. 9(10): 270-280. doi: https://doi.org/10.20546/ijcmas.2020.910.035 